\title{
Impact of Climate Variability on Hydrology of the Western Mitidja Watershed, Algeria
}

\author{
Faiza Hallouz, Hafsa Karahacane, Mohamed Meddi, Gil Mahe, Fadhila Sadi, Hanane Benchikh, \\ and Faiza Kemmerchou
}

\section{Keywords}

Hydro - Climatic regimes - Mitidja West - Ruptures - Simulation of the discharges from rains

\section{Introduction}

Algeria is a country located in the North of Africa. Its climate is mainly semi-arid but also undergoes an important Mediterranean influence. Also, a change in rainfall is likely to lead to a change in the availability of water resources. The impacts on living things in these regions should therefore be significant. The western Mitidja basin risks, like many areas in Africa, being negatively affected by climate change. This motivated us to study the vulnerability of this basin, especially its surface waters, a fundamental element of development.

\section{Materials and Methods}

\subsection{Study Area}

The plain of Mitidja is located in the south of Algiers. It extends over the territories of Algiers, Boumerdes, Tipaza and Blida. With a WSW-ENE orientation and an average

F. Hallouz $(\bowtie) \cdot$ H. Karahacane $\cdot$ M. Meddi

Engineering Laboratory of Water and Environment, ENSH, Blida,

Algeria

e-mail: hallouzfaiza@gmail.com

G. Mahe

IRD, Montpellier, France

F. Sadi

Laboratory of Local Natural Bio-Resources, Faculty of Science,

University Hassiba Ben Bouali, Chlef, Algeria

H. Benchikh · F. Kemmerchou

University Djilali Bounaama of Khemis Miliana, Ain Defla,

Algeria altitude of $100 \mathrm{~m}$, it covers an area of $1300 \mathrm{~km}^{2}$. This region is split into two geographical areas, the East Mitidja and the West Mitidja. The Mitidja West, which constitutes our study area, receives a total rainfall of about $616.1 \mathrm{~mm} /$ year, of which $84.7 \%$ evaporates, $2.63 \%$ infiltrates and $12.67 \%$ flows.

\subsection{Regionalization Using the Regional Vector Method}

Then, we chose to carry out the regionalization using the regional vector method via the Hydraccess software, which objective is to reconstitute the missing rainfall data at the monthly and annual time step (Singla 2009).

\subsection{Rupture Detection Tests on Time Series}

A statistical approach was used to help us better analyze monthly and annual rainfall. Khronostat is a statistical analysis software of time series of which several tests of detection of ruptures are available. We have chosen those that allow us to determine ruptures dates: Pettit's nonparametric method, Bayesian method of Lee and Heghinian, and Hubert's segmentation (Hallouz et al. 2011).

\subsection{Modeling Rainfall Discharge}

The model used in this study is the GR2M model (2-parameter Rural Model) which is a two-parameter rainfall-discharge model (Makhlouf 1994; Perrin et al. 2003). 


\subsection{Rainfall Data}

The rainfall data come mainly from the database of the National Agency for Hydraulic Resources (ANRH). They are recorded from 23 rainfall stations spread over the catchment and whose size of observations varies from one station to another. Indeed, we divided the western Mitidja basin into two parts.

\subsection{Runoff Data}

The data bank for monthly flows comes from the National Agency for Hydraulic Resources (ANRH) of Blida.

The time series generally concern the period 1987-2012, but are of variable durations.

\section{Results and Discussion}

\subsection{Regional Vector Results}

It should be noted that in the dataset used for this study, the number of stations is high only during the period from 1973 to 2005. It can also be seen in both regions that the fluctuation of the annual rainfall index decreases with the number of stations observed per year. Indeed, 1982 and 1998, the indices of annual rainfall fluctuate with great amplitude and are then representative only of a small number of stations. And since 1979 until 1986, the observed stations are more numerous and the index of annual rainfall calculated by the regional vector is then more representative and has its variability reduced according to the years. This allows us to conclude that the amount of data constitutes a limit of the quality of annual rainfall indices of the regional vectors.

\subsection{Rupture Results Interpretation and Analysis}

The monthly and annual ruptures detected at rainfall stations show the rain evolution during the study period. A decrease in rainfall from the 70 s was recorded at all study area stations. The deficit varies between 18.6 and $29.9 \%$.

Indeed, a sharp decline at the stations studied since the 1970s and generally at the level of the western Mitidja basin. A decrease in flows was recorded on all the stations of the study area from the $70 \mathrm{~s}$.

\subsubsection{Results of Calibration and Validation of the GR2M Model}

The calibration of the model generally requires the use of some of the available data (Refrsgaard and Abbot 1996).
Indeed, in order to determine the internal fit parameters of the model, the adopted calibration method, called "solver", shows that the hydrographs simulated by GR2M agree better with the hydrographs observed, which translates acceptable and superior Nash values to $60 \%$. It can be said that the model simulation quality is good. Validation is an crucial part of the model development process. Like the calibration phase, we can establish the Nash criterion for each basin. The numerical result gave us Nash satisfactory $99,9 \%$ for Boumedfaa and $100 \%$ for the Fer à cheval and Afroun stations.

\section{Conclusion}

The Mitidja West region is subject to a sub humid regional climate; its watershed contains many climatic and hydrological stations, although their distribution remains heterogeneous. The monthly and annual ruptures detected at these stations clearly show the evolution of the rain during the study period, a decrease in rainfall was recorded at all stations in the study area.

For the rainfall flow simulations, the efficiency of the model to simulate the monthly flows of the basin is given by the Nash criterion analysis, which has given satisfactory values greater than $(60 \%)$. Therefore we can say that the GR2M model has a certain efficiency in simulating the flows at the monthly time step and to guarantee a better understanding of the hydrological behavior of the basin.

Finally, in order to evaluate whether the climate or man-made hydraulic developments were the cause of the decrease in flows, we compared the dates of the ruptures detected on the hydrological series at the dam construction dates of western Mitidja and the results obtained showed that it was more the decrease of rainfall that impacted the construction of the Bouroumi dam in 1985.

\section{References}

Hallouz F, Meddi M, Mahe G. Analyse des ruptures dans les séries pluviométriques dans le bassin de l'oued Mina (Nord Ouest d'Algérie), Atelier SIG-MED Rabat 29 SEPTEMBRE; 2011. p. 28.

Makhlouf Z. Compléments sur le modèle pluie-débit GR4 J et essai d'estimation de ses paramètres. Thèse de Doctorat: Université de Paris XI Orsay/ Cemagref (Antony); 1994. p. 228.

Perrin C, Michel C, Andréassian V. Improvement of parsimonious model for stream flow simulation. J. Hydrologique. 2003;279(1):275-89.

Refrsgaard JC, Abbot MB. The role of distributed hydrological modeling in water resource management. Indistributed hydrological modling, Refsgaard (ED) kluwer Academies Publishers, Netherlands; 1996. p. 1-18.

Singla S, Impact du changement climatique global sur les régimes hydroclimatiques au Maroc tendances, ruptures et effets anthropiques sur les écoulements, mémoire de mastère2, Département des Sciences de la Terre de l'Eau et de l'Environnement de Montpellier; 2009. p. 90. 